Sains Malaysiana 50(2)(2021): 339-349

http://dx.doi.org/10.17576/jsm-2021-5002-06

\title{
Study of Thermostable Chitinase Isolated and Purified From Oryctes rhinoceros Larvae Gut
}

(Kajian Kitinase Termostabil Diasing dan Ditulenkan daripada Perut Larva Kumbang Tanduk Oryctes rhinoceros)

\author{
Aisyah Nabila Idris, Tang Swee SeOng \& Ahmad Faris Mohd Adnan*
}

\begin{abstract}
A chitinase-producing bacteria was locally isolated from rhinoceros beetle (Oryctes rhinoceros) larvae gut discovered in mushroom compost. A strain was selected from the source and labeled as RBLG1. It was identified using 16s rDNA sequencing and has strong homology to Bacillus cereus. Chitinase produced from RBLG1 was purified using ammonium sulfate precipitation, ion exchange chromatography, and gel filtration. The purified chitinase from RBLG1 shows the homogeneity 1.9 fold after the gel filtration process. The purified chitinase was identified and analyzed using $S D S-P A G E$ and the molecular mass from the strain was approximately $40 \mathrm{kDa}$. Further assays were performed to study the effect of temperature, $\mathrm{pH}$, and metal ion on the purified enzyme. The purified enzyme shows highest chitinase activity at $\mathrm{pH} 4$ and $60^{\circ} \mathrm{C}$. For metal ion test, chitinase from RBLG1 was unaffected when treated by various ions. Kinetic performance of chitinase using Michaelis-Menten equation shows $K_{m}$ and $V_{\max }$ values were $2.3 \mathrm{mM}$ and 0.0294 [P] mM/ min, respectively.
\end{abstract}

Keywords: Chitinase; Michaelis-Menten; purification; rhinoceros beetle larvae

\section{ABSTRAK}

Bakteria yang dapat menghasilkan kitinase ini telah diasingkan daripada perut larva kumbang tanduk (Oryctes rhinoceros) yang ditemui di dalam kompos cendawan. Satu strain bakteria dipilih daripada sumber tersebut dan dilabel sebagai RBLG1. Ia telah dikenal pasti menggunakan urutan 16s rDNA dan mempunyai homologi kuat kepada Bacillus cereus. Kitinase yang dihasilkan daripada RBLG1 ini kemudian menjalani proses penulenan menggunakan pemendakan amonium sulfat, kromatografi pertukaran ion dan penapisan gel. Kitinase yang dibersihkan daripada RBLG1 menunjukkan homogeniti 1.9 kali ganda selepas proses penapisan gel. Kitinase yang telah dibersihkan telah dikenal pasti dan dianalisis dengan menggunakan SDS-PAGE dan jisim molekul adalah pada saiz $40 \mathrm{kDa}$. Kajian lanjut dijalankan untuk mengkaji kesan enzim pada suhu, pH, kepekatan substrat dan juga ion logam pada enzim yang telah dibersihkan. Enzim yang ditulenkan menunjukkan aktiviti tertinggi pada pH 4 dan $60^{\circ} \mathrm{C}$. Bagi ujian ion logam, kitinase daripada RBLG1 tidak menunjukkan perubahan apabila ditindakkan dengan pelbagai ion. Kajian prestasi kinetik bagi kitinase dilakukan menggunakan prinsip Michaelis-Menten menunjukkan nilai Km dan Vmax masing-masing adalah $0.3 \mathrm{mM}$ dan $0.0294[\mathrm{P}] \mathrm{mM} / \mathrm{min}$.

Kata kunci: Kitinase; larva kumbang tanduk; Michaelis-Menten; penulenan

\section{INTRODUCTION}

Chitin had been recognized as the second most abundant biomass after cellulose and it is estimated that about 10 gigatonnes are available annually (Prashantha \& Tharanathan 2007). Chitin is a main constituent of arthropod cuticles, crustacean cells and also found in lower organisms such as yeast and algae (Sieber et al. 2018). The accumulation of chitin presents a problem in its disposal due its insolubility and inertness nature to chemical agents. Chitin produced from crustacean shell wastes via acid digestions is not environmental friendly as it produces acidic by products that needed to be remediated (Wang et al. 2018), to overcome this, the use of enzymatic degradation or hydrolysis has been proposed because of its green characteristics (Kaur \& Dhillon 2015). It has been proven that chitin is biocompatible, biodegradable and with low toxicity characteristics and biological activities such as antimicrobial actions warrants further development for chitin (Pillai et al. 2009). Currently, the 
applications of chitin and its derivatives are widely used in different industrial fields such as in agriculture, pharmacy, biomedical, cosmetics, food, paper industry and also wastewater treatment (Al Sagheer et al. 2009; Eliah-AliKomi \& Hamblin 2016).

Chitinolytic enzymes are important in chitin degradation processes and they can be produced by many organisms including viruses, bacteria, fungi, insects, plants, and animals (Yan \& Fong 2015). Chitinases are a diverse group of enzymes and different chitinases possess different molecular structure, substrate specificity and catalytic mechanism (Hamid et al. 2013; Stoykov et al. 2016). Chitinases have been intensively studied by researchers in the last decades and the production of chitinases can be divided into several methods including two basic techniques, which are produced by the natural resource or by genetically modified organism followed by purification method (Duskova 2011). Different applications of chitinases produce from different organisms depending on their own physiology and use (Bhattacharya et al. 2007). Bacteria are known to be great medium for chitin degradation in nature for example, the degradation rate of chitin in the soil systems are interconnected with the bacterial colony present in the soil, however, it also must be correlated with $\mathrm{pH}$, temperature or successional stage of degradation process (Beier \& Bertilsson 2014). Previous work done by Anudhara and Revathi (2013) shows that chitinase producing bacteria are very effficient in bioconversions process and could have a very useful for application in biotechnology and medicine.

Thus, studies are required to enhance chitinolytic enzymes activities and their applications in industries. This paper describes the isolation of a chitinase-producing bacteria from rhinoceros beetle larvae gut as well as purification and analyzes the kinetic performance of the purified chitinase. The analysis of chitinases on several characteristics such as the effect of $\mathrm{pH}$, effect of temperature, effect of substrate concentration, and effect of metal ion on chitinase production using chitin from shrimp shells also studied in this research. Kinetic performance of chitinase was also performed as the information obtained could be important as it could be used in bioconversion process.

\section{MATERIALS AND METHODS}

\section{PREPARATION OF COLLOIDAL CHITIN AND ENRICHMENT MEDIUM}

Chitin was obtained from shrimp shells flakes purchased from Sigma Aldrich used in this experiment. Preparation of colloidal chitin was done according to Priya et al. (2011). Briefly, shrimp shell flakes were ground and sorted out according to size using $250 \mu \mathrm{m}$ sieves. Five grams of chitin powder was dissolved gradually into $60 \mathrm{~mL}$ of $37 \%$ hydrochloric acid (Merck, UK). The mixture was left overnight at room temperature with rigorous stirring. To precipitate out the dissolved chitin, the mixture was added into $200 \mathrm{~mL}$ of ice cold $95 \%$ ethanol (Systerm, Malaysia) while maintaing a rigorous mixing during the process. The chitin precipitate was recovered via centrifugation at $12000 \times \mathrm{g}, 4^{\circ} \mathrm{C}$ for $20 \mathrm{~min}$. The precipitate was recoverd using filter paper. The precipitate was washed with sterile distilled water until neutral ( $\mathrm{pH} 7.0)$. Then, it was removed from filter paper, weighted and stored in the dark at $4{ }^{\circ} \mathrm{C}$ (Priya et al. 2011). Enrichment medium contained; colloidal chitin -10 g, $\mathrm{Na}_{2} \mathrm{HPO}_{4}$ (Systerm, Malaysia) -6 g, $\mathrm{KH}_{2} \mathrm{PO}_{4}$ (Systerm, Malaysia) -3 g, $\mathrm{NH}_{4} \mathrm{Cl}$ (Systerm, Malaysia) -1 g, $\mathrm{NaCl}$ (Systerm, Malaysia) - 0.5 g, Yeast extract (Difco, USA) -0.05 g, Agar (Difco, USA) $-15 \mathrm{~g}$, in $1 \mathrm{~L}$ distilled water. Enrichment medium was prepared and $\mathrm{pH}$ was set to $\mathrm{pH}$ 7. The enrichment media were labeled as colloidal chitin agar (CCA) and colloidal chitin broth $(\mathrm{CCB})$.

\section{SCREENING AND ISOLATION OF CHITIN DEGRADING BACTERIA}

Samples from rhinoceros beetle larva gut were collected from mushroom compost in Biotechnology Research Centre Glami Lemi, Negeri Sembilan and incubated in $100 \mathrm{~mL} \mathrm{CCB}$ for $1-7$ days at $37^{\circ} \mathrm{C}$ with constant shaking at $150 \mathrm{rpm}$. By using the spread plate method, samples were cultured onto CCA. The cultured plate was incubated at $27 \pm 2{ }^{\circ} \mathrm{C}$ for 1-7 days. Serial dilution was done before applying the spread plate method in the experiment is to avoid the CCA plate from overgrown with microorganisms. Isolates were selected on the basis of clear zone appearance around the colonies as this indicates the production of extracellular chitinase by the colonies. The selected strains were purified using serial streaking method on CCA plate. The pure bacterial colony obtained from the plates was then preserved (Anuradha \& Revathi 2013).

\section{IDENTIFICATION OF CHITIN DEGRADING BACTERIA}

The isolated strain RBLG1 was identified using 16S rDNA sequencing. The bacterial $16 \mathrm{~S}$ rDNA, full length $1.5 \mathrm{~kb}$, was amplified using universal primers $27 \mathrm{~F}$ and $1492 \mathrm{R}$. The total reaction volume of $25 \mu \mathrm{L}$ contained gDNA purified using a standard extraction method, $0.3 \mathrm{pmol}$ of each primer, deoxynucletides triphosphates (dNTPs, 400 $\mu \mathrm{M}$ each), 0.5 U DNA polymerase, supplied PCR buffer and water. The PCR was performed as follow, 1 cycle $(94$ ${ }^{\circ} \mathrm{C}$ for $\left.2 \mathrm{~min}\right)$ for initial denaturation; 25 cycles $\left(98^{\circ} \mathrm{C}\right.$ for $10 \mathrm{~s} ; 53{ }^{\circ} \mathrm{C}$ for $30 \mathrm{~s} ; 68{ }^{\circ} \mathrm{C}$ for $1 \mathrm{~min}$ ) for annealing and extension of the amplified DNA. The PCR products were 
purified by standard method and directly sequenced with primers $785 \mathrm{~F}$ and $907 \mathrm{R}$ using BigDye ${ }^{\circledR}$ Terminator v3.1 Cycle Sequencing Kit (Applied Biosystems). Searching for sequence similarity was conducted using NCBI BLAST system and the nearest relatives of the $16 \mathrm{~S}$ rDNA were identified using GenBank database.

\section{CHITINASE PRODUCTION AND EXTRACTION}

The preserved pellet in the glycerol was inoculated into enrichment media $(\mathrm{pH} 7)$ containing colloidal chitin -10 g, $\mathrm{Na}_{2} \mathrm{HPO}_{4}$ (Systerm, Malaysia) -6 g, $\mathrm{KH}_{2} \mathrm{PO}_{4}$ (Systerm, Malaysia) -3 g, $\mathrm{NH}_{4} \mathrm{CL}$ (Systerm, Malaysia) -1 g, NaCl (Systerm, Malaysia) -0.5 g, Yeast extract (Difco, USA) $0.05 \mathrm{~g}$. It was incubated at $37^{\circ} \mathrm{C}$ for $48 \mathrm{~h}$. Cultures were harvested by centrifugation at $12000 \times \mathrm{g}$ for $20 \mathrm{~min}$ at 4 ${ }^{\circ} \mathrm{C}$. The supernatant obtained was collected and was used as crude enzymes sources (Suryanto et al. 2012).

\section{PURIFICATION OF CHITINASES AMMONIUM SULFATE PRECIPITATION}

Ammonium sulfate $(608 \mathrm{~g} / \mathrm{L})$ was added to the crude enzyme and the mixture was stored at $4{ }^{\circ} \mathrm{C}$ overnight. The precipitate formed was collected by centrifugation at $4{ }^{\circ} \mathrm{C}$ for $20 \mathrm{~min}$ at $12000 \times \mathrm{g}$. The precipitate was dissolved in $0.1 \mathrm{M}$ sodium phosphate buffer $(\mathrm{pH} \mathrm{7})$ and dialyzed against the buffer for two days.

\section{SIZE EXCLUSION CHROMATOGRAPHY USING SEPHACRYL S-100 CHROMATOGRAPHY}

$3 \mathrm{~mL}$ dialysate was loaded into a sephacryl S-100 gel filtration column. The column was equilibrated and eluted with $50 \mathrm{mM}$ sodium phosphate buffer $(\mathrm{pH} \mathrm{7)}$ (Liang et al. 2014). The fractions with high elution peak were collected and chitinase activities were assayed. The fraction containing the highest chitinase activity was collected and concentrated by adding ammonium sulfate (608 g/L) (Wang et al. 2015). The mixture was left overnight and the precipitate formed was collected by centrifugation and dissolved in $5 \mathrm{~mL}$ of $50 \mathrm{mM}$ sodium phosphate buffer $(\mathrm{pH} 7)$ then dialyzed against the buffer for $48 \mathrm{~h}$ (Liang et al. 2014).

\section{ION EXCHANGE CHROMATOGRAPHY USING DEAE- SEPHAROSE CL-6B CHROMATOGRAPHY}

DEAE-sepharose CL-6B purchased from Sigma Aldrich was packed into column chromatography. Three $\mathrm{mL}$ of the resultant enzyme solution from ion exchange chromatography was loaded onto the DEAE-Sepharose CL-6B column. The column was equilibrated with $50 \mathrm{mM}$ sodium phosphate buffer ( $\mathrm{pH} 7$ ). The enzyme solution was washed and eluted with the $0-1 \mathrm{M} \mathrm{NaCl}$ linear gradient in the same buffer. Ten $\mathrm{mL}$ of $0.2,0.4,0.6,0.8$, and $1.0 \mathrm{M}$ of $\mathrm{NaCl}$ in $50 \mathrm{mM}$ sodium phosphate buffer were used as eluent buffer solutions. The fractions were collected and the chitinase activity was measured. The fraction with the highest chitinase activity was chosen and concentrated using ammonium sulfate $(608 \mathrm{~g} / \mathrm{L})$. The precipitate formed was collected by centrifugation and dissolved in $2 \mathrm{~mL}$ of $50 \mathrm{mM}$ sodium phosphate buffer $(\mathrm{pH}$ 7) (Liang et al. 2014). Then, it was dialyzed against the same buffer for $48 \mathrm{~h}$. The collected protein (dialysate) was stored and used in characterization.

\section{PROTEIN DETERMINATION}

Protein concentration was measured using Bradford Assay. Bovine serum albumin (BSA) was used as a standard solution and the absorbance was measured at 595 nm (Anuradha \& Revathi 2013).

\section{CHITINASE ASSAY}

Chitinase activity was determined by measuring reducing sugar hydrolyzed from colloidal chitin utilizing dinitrosalicylic acid (DNS) method by Miller (1959). $0.5 \%(\mathrm{w} / \mathrm{v})$ colloidal chitin was added in $0.5 \mathrm{~mL}$ phosphate buffer ( $\mathrm{pH} 5.5$ ) and used as substrate. The mixture of 0.5 $\mathrm{mL}$ enzyme solution and $1 \mathrm{~mL}$ substrate was incubated at $37{ }^{\circ} \mathrm{C}$ for $30 \mathrm{~min}$ (Liang et al. 2014). Three $\mathrm{mL}$ DNS reagent was added and it was heated at $100{ }^{\circ} \mathrm{C}$ for 10 min. Then, $1 \mathrm{~mL}$ of Rochelle's salt solution was added to the mixture. The mixture was centrifuged at $1000 \mathrm{rpm}$ for $5 \mathrm{~min}$. The supernatant was collected and measured at $530 \mathrm{~nm}$. Under assay condition, one unit (U) of chitinase activity is defined as the amount of enzyme that is required to release $1 \mu \mathrm{mol}$ of $\mathrm{N}$-acetylglucosamine per min from $0.5 \%(\mathrm{w} / \mathrm{v})$ of colloidal chitin solution (Sudhakar \& Nagarajan 2010).

\section{DETERMINATION OF MOLECULAR MASS OF PURIFIED CHITINASE}

The molecular mass of the purified chitinase can be determined using SDS-Polyacrylamide gel electrophoresis using $12.5 \%$ acrylamide gel. The sample solution was heated at $95{ }^{\circ} \mathrm{C}$ for $4 \mathrm{~min}$ in dissociation buffer (pH 6.8) containing 0.5 M Tris $\mathrm{HCl}, 40 \%$ glycerol, $8 \%$ SDS and $0.05 \%$ Bromophenol Blue. The gel was stained using Coomassie Brilliant Blue R-250 overnight (Ikeda et al. 2009).

\section{EFFECT OF PH AND TEMPERATURE ON CHITINASE ACTIVITY}

Chitinase activity was assayed at different $\mathrm{pH}$ values $(\mathrm{pH}$ 4.0 to 9.0 ) and different temperature ranging from 25 to $80{ }^{\circ} \mathrm{C}$ (Liang et al. 2014a). 
EFFECT OF SUBSTRATE CONCENTRATION AND METAL ION ON CHITINASE ACTIVITY

Enzyme activity for chitinase was measured at different substrate concentration (Anuradha \& Revathi 2013) and metal ions such as $\mathrm{K}^{+}, \mathrm{Ca}^{2+}, \mathrm{Zn}^{2+}, \mathrm{Fe}^{2+}$, and $\mathrm{Cu}^{2+}$ were applied in amount of $5 \mathrm{mM}$ to see the ions effects to activity of the purified enzyme (Annamalai et al. 2010).

\section{DETERMINATION OF KINETIC PERFORMANCE ON} CHITINASE USING MICHAELIS-MENTEN EQUATION

To study the $\mathrm{K}_{\mathrm{m}}$ and $\mathrm{V}_{\text {max }}$ of purified chitinase, the enzymes were incubated with colloidal chitin at various concentrations from 1.13 to $7.91 \mathrm{mM}$. The colloidal chitin was mixed with $50 \mu \mathrm{L}$ enzyme in $0.2 \mathrm{M}$ phosphate buffer (pH 8.0) and incubated at $50{ }^{\circ} \mathrm{C}$ for $20 \mathrm{~min}$ (Han et al. 2008). Reducing sugar was measured and using standard DNS assay and the data were recorded. The $\mathrm{K}_{\mathrm{m}}$ and $\mathrm{V}_{\text {max }}$ values were extrapolated using Polymath 6.0.

\section{RESULTS AND DISCUSSION}

\section{IDENTIFICATION OF THE CHITINASE PRODUCING} STRAIN

Two isolates from rhinoceros beetle larvae gut were isolated and labelled as RBLG1 and RBLG2. One out of two isolates that showed the highest chitinase activity was selected which is RBLG1. The morphological characteristics of the isolate known as RBLG1 was identified as Gram positive bacillus, rod shape, with creamlike colony and grows in aerobic condition.

RBLG1 was identified similar as Bacillus sp. using 16s rDNA sequencing and the report of PCR and phylogenetic tree for RBLG1 was shown in Figures 1 and 2 , respectively. Figure 1 shows that the amplification bands from RBLG1 consist of $2500 \mathrm{bp}$ in length. BLASTN report for RBLG1 strain indicates high maximum score and a lower E-value which indicates a good BLASTN was achieved. When the E-value is lower, less likely the similarities happened by chances or random similarity. RBLG1 was labeled as 'Chi' in the phylogenetic tree in Figure 2.

This is in conccurance with other works on chitinase that shown various Bacillus species and strain have the ability to breakdown chitin such as $B$. cereus TKU030 (Liang et al. 2014), B. subtilis TV-125 (Senol et al. 2014), B. cereus TKU028 (Liang et al. 2014), B. licheniformis SK-1 (Kudan 2009), B. licheniformis MKU3 (Radha 2009), and B. subtilis JN032305 (Shivakumar 2014).
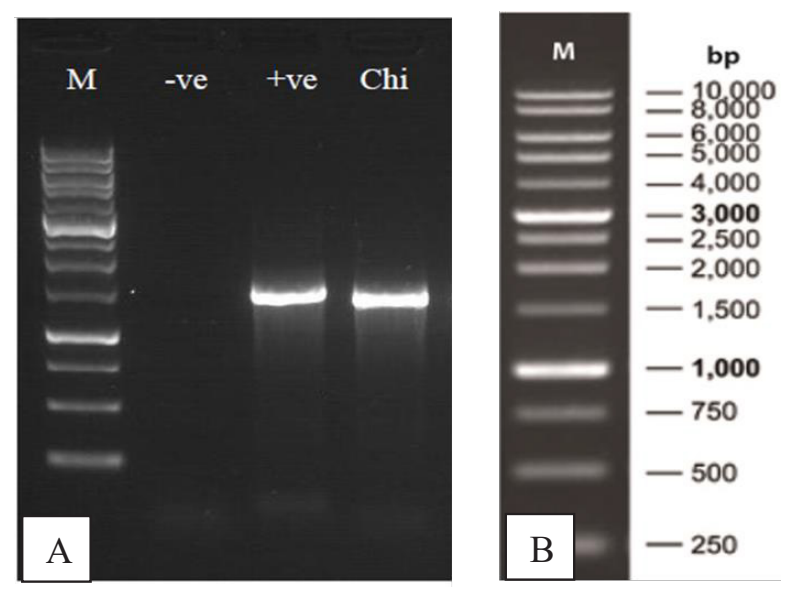

FIGURE 1. (A) Gel electrophoresis for RBLG1 strain labelled as 'Chi', (B) DNA ladder. Figure (A) shows PCR amplification of 16S rDNA gene of agarose gel electrophoresis and (B) shows DNA marker which acts as indicator for the length of RBLG1 




FIGURE 2. Phylogenetic tree for RBLG1 strain labelled as 'Chi'

\section{PURIFICATION OF THE CHITINASES FROM STRAIN RBLG1}

After incubated for $48 \mathrm{~h}$ at $37^{\circ} \mathrm{C}$ in media containing colloidal chitin, chitinases from RBLG1 strains was purified by ammonium sulfate precipitation. Two steps chromatographic techniques which are ion exchange chromatography and gel filtration chromatography were used. Enzyme purification was performed and the summary of the fractions was presented in Table 1.

Protein concentration and chitinase activity were measured for all sample from different fractions. The specific activity for chitinase from RBLG1 was $0.36 \mathrm{U} /$ $\mathrm{mg}$ in crude extract, and $0.69 \mathrm{U} / \mathrm{mg}$ in gel filtration, which gives 1.9 purification fold. The chitinases yield for RBLG1. The recovery of chitinase activity was low throughout the enzyme purification processes might be due to several reasons such as the synergistic action of different isoforms in crude enzyme and a loss of chitinase activity upon purification (Liang et al. 2014). The loss of protein after each step also contributed to the low chitinase activity. Comparison between other works that utilizes ammnonium sulfate precipitation technique to obtain crude extract of chitinase, shown that the saturation levels of chitinase enzymes ranges from 30 to $85 \%$ salt content (Farag \& Al-Nusarie 2014).

TABLE 1. RBLG1 enzyme purification table

\begin{tabular}{lccccc}
\hline Fractions & Protein $(\mathrm{mg})$ & Total activity $(\mathrm{U})$ & $\begin{array}{c}\text { Specific activity } \\
(\mathrm{U} / \mathrm{mg})\end{array}$ & $\begin{array}{c}\text { Purification } \\
(\text { Fold })\end{array}$ & Yield (\%) \\
\hline Crude & 68.86 & 24.95 & 0.36 & 1.00 & 100.0 \\
$\begin{array}{l}\text { Ammonium sulphate } \\
\text { fractionation }\end{array}$ & 31.61 & 11.77 & 0.37 & 1.03 & 47.2 \\
$\begin{array}{l}\text { Ion exchange } \\
\text { Gel filtration }\end{array}$ & 14.36 & 7.19 & 0.50 & 1.38 & 28.8 \\
& 4.91 & 3.38 & 0.69 & 1.90 & 13.5 \\
\hline
\end{tabular}




\section{MOLECULAR WEIGHT DETERMINATION}

Molecular weight for the strain in each fraction was identified. SDS-PAGE was performed for the purified chitinase and the result was shown in Figure 3.

Lanes : M, protein markers; 1 , crude enzyme; 2 , ammonium sulfate precipitation; 3, chitinase fraction after Sephacryl S-100; 4, chitinase fraction after DEAESepharose CL-6B chromatography.
The molecular weight for the purified chitinase was calculated by comparing it with the standard protein marker. As shown in Figure 3, the lane 4 shows a band located approximately $40 \mathrm{kDa}$ for purified chitinase from RBLG. The result obtained is comparable to Liang et al. (2014) and Ueda and Kurosawa (2015), with a molecular mass of ranging from 43 to $48 \mathrm{kDa}$ from purified chitinase obtained Bacillus cereus and Paenibacillus thermoaerohilus, respectively.

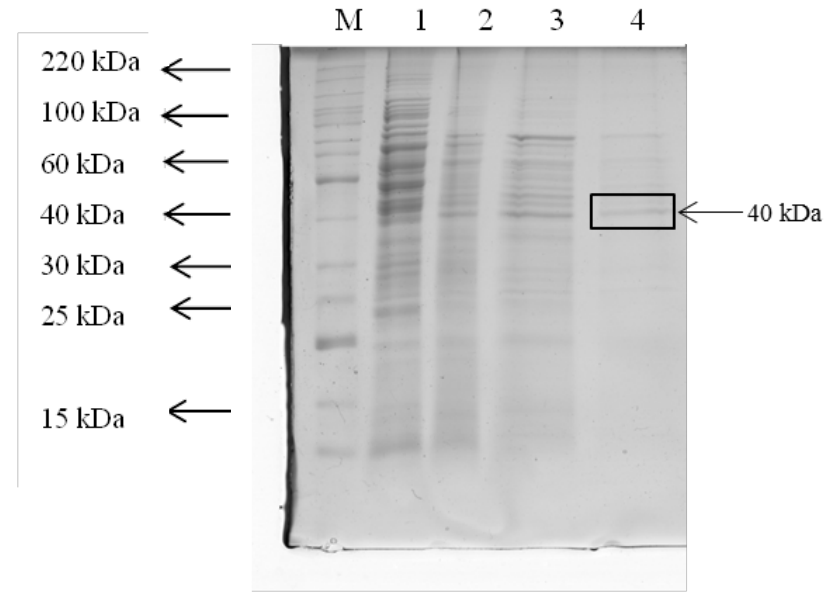

FIGURE 3. SDS-PAGE analysis of chitinase fractions produced by RBLG1. Lanes : M, molecular markers; 1, culture supernatant; 2, crude enzyme; 3 , chitinase fraction after Sephacryl S-100; 4, chitinase fraction after DEAE-Sepharose CL-6B chromatography

THE EFFECT OF PH, TEMPERATURE, AND METAL ION ON PURIFIED CHITINASE ACTIVITY AND STABILITY

Enzyme activity for RBLG1 strain was assayed after preincubating at different temperature for $1 \mathrm{~h}$. Then, by using a standard assay, the chitinases activity were measured and recorded. The values are mean $\pm \mathrm{SD}, \mathrm{n}=3$.

The performance of purified chitinase from RBLG1 was determined by assaying the enzyme in six different $\mathrm{pH}$ buffer solution at $37^{\circ} \mathrm{C}$ for $30 \mathrm{~min}$. Enzyme activity was measured using standard assay conditions. The highest chitinase activity for RBLG1 is $60^{\circ} \mathrm{C}$ as shown in Figure 4. RBLG1 strain shows the highest chitinase activity at 60 ${ }^{\circ} \mathrm{C}$ is because the rhinoceros beetle larvae were collected from spent mushroom compost pile that has temperature range monitored between 50 and $60^{\circ} \mathrm{C}$. Figure 5 shows the effect of $\mathrm{pH}$ on chitinase activity for RBLG1. The values are mean $\pm \mathrm{SD}, \mathrm{n}=3$. The chitinase produced by RBLG1 shows the highest chitinase activity which is $0.0330 \mathrm{U} /$ $\mathrm{mL}$ at $\mathrm{pH} 4$, this is in agreement with previous studies (Wada et al. 2014) that reported the optimum $\mathrm{pH}$ for the activity for $N$-acetyl-glucosaminidase was within the range $\mathrm{pH} 4.1$ to 5.2. This result is also comparable with other works done to investigate the optimum temperature and $\mathrm{pH}$ of chitinase. Table 2 shows comparative information on optimum temperature and $\mathrm{pH}$ of chitinase from various microbial species. Ueda and Kurosawa (2015) reported chitinase with similar characteristics from Paenibacillus thermoaerohilus TCC22-2b that was isolated from compost while Kumar et al. (2018) reported that chitinase obtained from Humicola grisea exhibited a higher optimum 
temperature of $70^{\circ} \mathrm{C}$ and $\mathrm{pH}$ of 3 . This shows that certain chitinase could operate at high temperature and low $\mathrm{pH}$ that enable its applicability for a bioconversion of chitin to other valued products such as chitosan and N-acetyl-Dglucosamine. The values are mean $\pm S D, n=3$.

Table 3 shows the effect of five different metal ions on chitinase activity. There is no significant effect of metal ions on the activity of the enzyme with less than $5 \%$ decreases and not more $2 \%$ increases of the enzyme activity when subjected to the metal ions. This indicated that the chitinase from RBLG1 is a stable and robust enzyme, able to perform its duty without any hinderance. This is in contrast with the chitinase isolated from Chitinbacter sp. GC72 with its relative activity reduced to $64 \%$ when treated with $10 \mathrm{mM} \mathrm{Zn}^{2+}$ ions (Gao et al. 2015). All values are mean $\pm \mathrm{SD}, \mathrm{n}=3$.

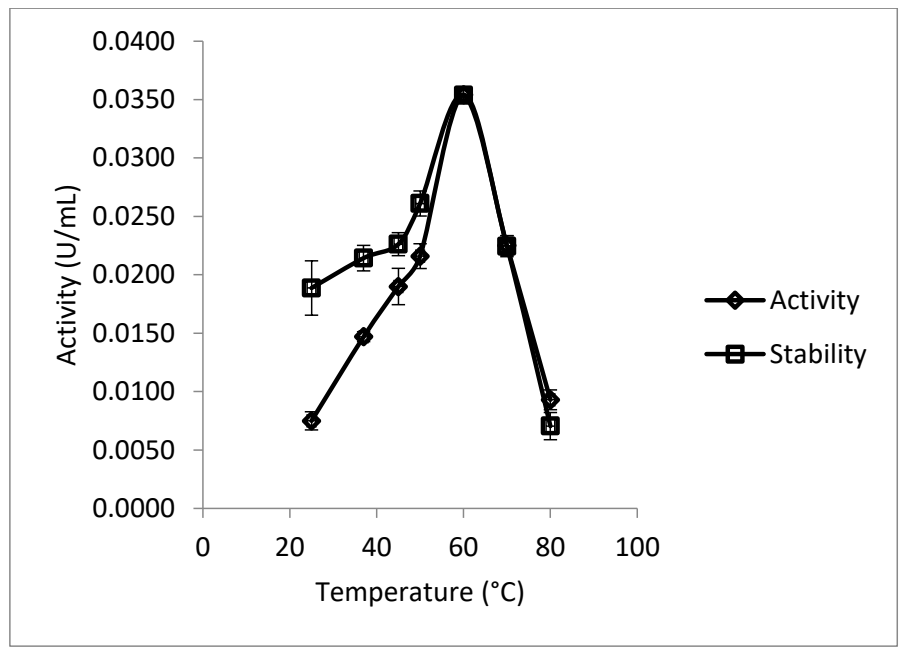

FIGURE 4. Effect of temperature on chitinase activity and stability for RBLG1. The temperature used were $25,37,45,50,60,70$ and $80^{\circ} \mathrm{C}$.

The values were mean $\pm S D, n=3$



FIGURE 5. Effect of $\mathrm{pH}$ on chitinase activity and stability for RBLG1. The $\mathrm{pHs}$ used were $\mathrm{pH} 4,5,6,7,8$ and 9 . The values were mean $\pm \mathrm{SD}, \mathrm{n}=3$ 
TABLE 2. Some comparison amongst chitinases recently described

\begin{tabular}{|c|c|c|c|c|}
\hline Organisms & $\begin{array}{l}\text { Optimum temperature } \\
\left({ }^{\circ} \mathrm{C}\right)\end{array}$ & Optimum $\mathrm{pH}$ & Molecular mass (kDa) & References \\
\hline Bacillus cereus RBLG1 & 60 & 4 & 40 & This work \\
\hline $\begin{array}{l}\text { Bacillus safensis } \\
\text { MBCU6 }\end{array}$ & 60 & 7 & 58 & $\begin{array}{l}\text { Pandya and Saraf } \\
\qquad(2015)\end{array}$ \\
\hline $\begin{array}{c}\text { Paenibacillus } \\
\text { thermoaerohilus TC22- } \\
2 \mathrm{~b}\end{array}$ & 60 & 4 & 48 & $\begin{array}{l}\text { Ueda and Kurosawa } \\
\qquad(2015)\end{array}$ \\
\hline $\begin{array}{l}\text { Paenicibacillus } \\
\text { barengoltzii }\end{array}$ & 60 & 3.5 & 67 & Fu et al. (2016) \\
\hline $\begin{array}{l}\text { Hydrogenophilus } \\
\text { hirschii KB-DZ44 }\end{array}$ & 85 & 5 & 59.1 & Bouacem et al. (2018) \\
\hline Humicola grisea & 70 & 3 & 50 & Kumar et al. (2018) \\
\hline Thermobifida fusca & 30 & 6 & 44.9 & Yan and Fong (2018) \\
\hline Streptomyces F-3 & 70 & 5 & 63.89 & Sun et al. (2019) \\
\hline
\end{tabular}

TABLE 3. Effects of metal ions on chitinase activity

\begin{tabular}{cc}
\hline Metal ions (5 mM) & Relative activity (\%) \\
\hline None & 100 \\
$\mathrm{KCl}$ & 99.09 \\
$\mathrm{CaCl}_{2}$ & 99.39 \\
$\mathrm{ZnSO}_{4}$ & 96.96 \\
$\mathrm{FeSO}_{4}$ & 99.39 \\
$\mathrm{CuSO}_{4}$ & 102.13 \\
\hline
\end{tabular}

\section{DETERMINATION OF $V_{\text {MAX }}$ AND $K_{M}$ VALUES}

Kinetic performance for the strain was determined by using the Michaelis-Menten equation. Reducing sugar content was calculated for different colloidal chitin concentration at four- time intervals. Maximal velocity $\left(V_{\max }\right)$ and substrate concentration at half of the maximal velocity $\left(K_{m}\right)$ of RBLG1 was calculated using polynomial graphs. The $V_{\max }$ and $K_{m}$ values for the strain that had been calculated from the graph were $0.0294[\mathrm{P}](\mathrm{mM} / \mathrm{min})$ and $2.3 \mathrm{mM}$, respectively. Polymath 6.0 was used to prove the accuracy of the calculated $V_{\max }$ and $K_{m}$. As in Michaelis-
Menten equation stated that; $\mathrm{v}=V_{\max }[\mathrm{S}] /\left(K_{\mathrm{m}}+[\mathrm{S}]\right)$, the equation was used as input in the software and the values in the table were used as an initial guess. The nonlinear regression for RBLG1 was analyzed. Table 4 shows the analyzed data for the strain using nonlinear regression.

Affinity is the tendency of a certain enzyme to bind with a substrate. High $K_{m}$ indicates the enzyme has a low affinity towards its substrate and a lot of substrates must be present to saturate the enzyme. Alternatively, low $K_{m}$ will use a small amount of substrate as the enzyme has a high affinity for the substrate. According to Han et al. 
(2009), the higher $V_{\text {max }}$ and lower $K_{m}$ values indicated that the particular substrate is better for that particular enzyme. $V_{\max }$ value basically shows the rate of enzyme break down its substrate. The higher $V_{\max }$ value showing the enzymes works effectively. By using Polymath 6.0, the $\mathrm{R}^{2}$ shows the precision of the initial guess value towards the calculated data using the software. The $\mathrm{R}^{2}$ value for RBLG1 is 0.9258 . The $\mathrm{V}_{\max }$ and $\mathrm{K}_{\mathrm{m}}$ values obtained for chitinase from RBLG1 showed that the enzyme can be considered for industrial usage. Similar results were obtained by Halder et al. (2016) for the chitinase produced from Aeromonas hydrophila SBK1 showed fairly similar for $\mathrm{V}_{\max }$ dan $\mathrm{K}_{\mathrm{m}}$. This in contrast to the results obtained by Fu et al. (2016), Karthik et al. (2015) and Loni et al. (2014) on their bacterial isolates and chitinases have been touted for industrial usage but does not conform to the high $\mathrm{V}_{\text {max }}$ and low $\mathrm{K}_{\mathrm{m}}$ principle.

TABLE 4. Nonlinear regression report on RBLG1

\begin{tabular}{ccccc}
\hline Strain & Variable & Initial guess & Value & $\mathrm{R}^{2}$ \\
\hline \multirow{2}{*}{ RBLG1 } & $V_{\max }([\mathrm{P}](\mathrm{mM} / \mathrm{min})$ & 0.0298 & 0.042 & 0.9258 \\
& $K_{m}(\mathrm{mM})$ & 2.3 & 3.281 & \\
\hline
\end{tabular}

\section{CONCLUSION}

In summary, the results in this study show chitinase extracted from RBLG1 strain has a potential to be used in the conversion of agriculture waste such as spent mushroom compost, as the enzymes are thermostable, can react in acidic condition and with robust characteristics against metal ions inhibition. These characteristics enable a faster turnover by eliminating or reducing steps after pre-treatment procedures for bioconversion of spent mushroom compost into second generation fermentation feedstock. The RBLG1 strain itself has the potential to be a biocontrol agent for phytopathogenic fungus in a highly organic and acidic soil condition such as peat.

Recommendation for future study regarding the capability of chitinases isolated from several sources should be done on a large scale in order to fit the demand in industries. Further study on the conversion of seafood wastes and spent mushroom composed into second generation fermentation feedstock, for example, biodiesel, and bioethanol should be done by using purified enzymes from this experiment, or by using mixed enzymes to make the conversion more efficient. This is the time where we should take an alternative way to make use all the wastes in order to reduce the environmental pollution and as a replacement for non-renewable resources.

\section{ACKNOWLEDGEMENTS}

The authors would like to thank University of Malaya for providing research infrastructures, the postgraduate research grants (PG045-2015A), (PG239-2015B), (PG219-
2015A) and Skim Biasiswazah for the financial support. AFMA conceived and designed research. ANI conducted experiments. AFMA contributed reagents and analytical tools. ANI analyzed data. ANI, AFMA, TSS wrote the manuscript. All authors read and approved the manuscript. The authors declare that they have no conflict of interest.

\section{REFERENCES}

Al Sagheer, F., Al-Sughayer, M., Muslim, S. \& Elsabee, M.Z. 2009. Extraction and characterization of chitin and chitosan from marine sources in Arabian Gulf. Carbohydrate Polymers 77(2): 410-419.

Annamalai, N., Giji, S., Arumugam, M. \& Balasubramanian, T. 2010. Purification and characterization of chitinase from Micrococcus sp. AG84 isolated from marine environment. African Journal of Microbiology Research 4(24): 2822-2827.

Anuradha, V. \& Revathi, K. 2013. Purification and characterization of bacterial chitinase isolated from crustacean shells. International Journal of Pure and Applied Bioscience 1(4): $1-11$.

Bhattacharya, D., Nagpure, A. \& Gupta, R.K. 2007. Bacterial chitinases: Properties and potential. Critical Reviews in Biotechnology 27(1): 21-28.

Beier, S. \& Bertilsson, S. 2014. Bacterial chitin degradation mechanisms and ecophysiological strategies. Frontiers in Microbiology 4: 149

Bouacem, K., Laribi-Habchi, H., Mechri, S., Hacene, H., Jaoudi, B. \& Bouanane-Darenfed, A. 2018. Biochemical characterization of a novel thermostable chitinase from Hydrogenophilus hirschii strain KB-DZ44. International Journal of Biological Macromolecules 106: 338-350. 
Duskova, J., Tishchenko, G., Ponomareva, E., Simunek, J., Koppova, I., Skalova, T. \& Dohnalek, J. 2011. Chitinolytic enzymes from bacterium inhabiting human gastrointestinal tract-critical parameters of protein isolation from anaerobic culture. Acta Biochimica Polonica 58(2): 261-263.

Elieh-Ali-Komi, D. \& Hamblin, M.R. 2016. Chitin and chitosan: Production and application of versatile biomedical nanomaterials. International Journal of Advanced Research 4(3): 411-427.

Farag, M.A. \& Al-Nusarie, S.T. 2014. Production, optimization, characterization and antifungal activity of chitinase produced by Aspergillus terrus. African Journal of Biotechnology 13(14): 1567-1578.

Fu, X., Yan, Q., Wang, J., Yang, S. \& Jiang, Z. 2016. Purification and biochemical characterization of novel acidic chitinase from Paenicibacillus barengoltzii. International Journal of Biological Macromolecules 91: 973-979.

Gao, C., Zhang, A., Chen, K., Hao, Z., Tong, J. \& Ouyang, P. 2015. Characterization of extracellular chitinase from Chitinibacter sp. GC72 and its application in GlcNAc production from crayfish shell enzymatic degradation. Biochemical Engineering Journal 97: 59-64.

Halder, S.K., Jana, A., Paul, T., Das, D., Ghosh, K., Pati, B.R. \& Mondal, K.C. 2016. Purification and biochemical characterization of chitinase of Aeromonas hydrophila SBK1 biosynthesized using crustacean shell. Biocatalysis and Agricultural Biotechnology 5: 211-218.

Hamid, R., Khan, M.A., Ahmad, M., Ahmad, M.M., Abdin, M.Z., Musarrat, J. \& Javed, S. 2013. Chitinases: An update. Journal of Pharmacy and Bioallied Sciences 5(1): 21-29.

Han, Y., Yang, B., Zhang, F., Miao, X. \& Li, Z. 2009. Characterization of antifungal chitinase from marine Streptomyces sp. DA11 associated with south china sea sponge Craniella australiensis. Marine Biotechnology 11(1): 132-140.

Ikeda, M., Miyauchi, K., Mochizuki, A. \& Matsumiya, M. 2009. Purification and characterization of chitinase from the stomach of silver croaker Pennahia argentatus. Protein Expression and Purification 65(2): 214-222.

Karthik, N., Binod, P. \& Pandey, A. 2015. Purification and characterisation of an acidic and antifungal chitinase produced by a Streptomyces sp. Bioresource Technology 188: 195-201.

Kaur, S. \& Dhillon, G.S. 2015. Recent trends in biological extraction of chitin from marine shell wastes: A review. Critical Reviews in Biotechnology 35(1): 44-61.

Kudan, S. \& Pichyangkura, R. 2009. Purification and characterization of thermostable chitinase from Bacillus licheniformis SK-1. Applied Biochemistry and Biotechnology 157(1): 23-25.

Kumar, M., Brar, A., Vivekanand, V. \& Pareek, N. 2018. Process optimization, purification and characterization of a novel acidic, thermostable chitinase from humicola grisea. International Journal of Biological Macromolecules 116: 931-938.

Liang, T.W., Hsieh, T.Y. \& Wang, S.L. 2014. Purification of a thermostable chitinase from Bacillus cereus by chitin affinity and its application in microbial community changes. Soil Bioprocess and Biosystems Engineering 37(6): 1201-1209.

Loni, P.P., Patil, J.U.U., Phugare, S.S. \& Bajekal, S.S. 2014. Purification and acharacterizationfrom Paenibacillus pasadenensis NCIM 5434. Journal of Basic Microbiology 54(10): 1080-1089.

Oyerend, G., Luo, Y., Henderson, L., Douglas, A.E., Davies, S.A. \& Dow, J.A. 2016. Molecular mechanism and functional significance of acid generation in the Drosophila midgut. Scientific Report 6: 27242.

Pandya, U. \& Saraf, M. 2015. Purification and characterization of antifungal chitinase from Bacillus safensis MBCU6 and its application for production of chito-oligosaccharides. Biologia 70(7): 863-868.

Prashanth, K.H. \& Tharanathan, R.N. 2007. Chitin/chitosan: Modifcations and their unlimited application potential-an overview. Trends in Food Science \& Technology 18(3): 117-131.

Priya, C., Jagannathan, N. \& Kalaichelvan, P. 2011. Production of chitinase by Streptomyces hygroscopicus VMCH2 by optimisation of cultural conditions. International Journal of Pharma and Bio Sciences 2(2): 210-219.

Radha, S. \& Gunasekaran, P. 2009. Purification and characterization of keratinase from recombinant Pichia and Bacillus strain. Protein Expression and Purification 64(1): 24-31.

Sieber, V., Hofer, M., Brück, W.M., Garbe, D., Brück, T. \& Lynch, C.A. 2018. ChiBio: An integrated bio-refinery for processing chitin-rich bio-waste to specialty chemicals. In Grand Challenges in Marine Biotechnology, edited by Rampelotto, P.H. \& Trincone, A. Springer: Cham. pp. 555-578.

Senol, M., Nadaroglu, H., Dikbas, N. \& Kotan, R. 2014. Purification of chitinase from Bacillus subtilis bacteria TV-125, investigation of kinetic properties and antifungal activity against Fusarium culmorum. Annals of Clinical Microbiology and Antimicrobials 13: 35.

Shivakumar, S., Karmali, A.N. \& Ruhimbana, C. 2014. Partial purification, characterization, and kinetic studies of a low molecular weight, alkali-tolerant chitinase enzyme from Bacillus subtilis JN032305 a potential biocontrol strain. Preparative Biochemistry and Biotechnology 44(6): 617-632.

Stoykov, Y.M., Pavlov, A.I. \& Krastanov, A.I. 2015. Chitinase biotechnology: Production, purification, and application. Engineering in Life Sciences 15(1): 30-38.

Sudhakar, P. \& Nagarajan, P. 2010. Production of chitinase by solid state fermentation from rice bran. International Journal of Environmental Science and Development 1(5): 435-440.

Sun, X., Li, Y., Tian, Z., Qian, Y., Zhang, H. \& Wang, L. 2019. A novel thermostable chitinolytic machinery of Streptomyces sp. F-3 consisting of chitinases with different action modes. Biotechnology for Biofuels 12(1): 136-147.

Suryanto, D., Irawati, N. \& Munir, E. 2011. Isolation and characterization of chitinolytic bacteria and their potential to inhibit plant pathogenic fungi (short communication). Microbiology Indonesia 5(5): 144-148.

Ueda, J. \& Kurosawa, N. 2015. Characterization of an extracellular thermophilic chitinase from Paenibacillus 
thermoaerohilus strain $\mathrm{TC} 22-2 \mathrm{~b}$ isolated from compost. World Journal of Microbioloy and Biotechnology 31(1): 135-143.

Wada, N., Sunairi, M., Anzai, H., Iwata, R., Yamane, A. \& Nakajima, M. 2014. Glycolytic activities in the larval digestive tract of Trypoxylus dichotomus (Coleoptera: Scarabaeidae). Insects 5(2): 351-363.

Wang, D., Li, A., Han, H., Liu, T. \& Yang, Q. 2018. A potent chitinase from Bacillus subtilis for the efficient bioconversion of chitin-containing wastes. International Journal of Biological Macromolecule 116: 863-868.

Wang, J., Zhang, J., Song, F., Gui, T. \& Xiang, J. 2015. Purification and characterization of chitinases from ridgetail white prawn. Exopalaemon Carinicauda Molecules 20(2): 1955-1967.

Yan, Q. \& Fong, S.S. 2018. Cloning and characterization of a chitinase from Thermobifida fusca reveals Tfu 0580 as a thermostable acidic endochitinase. Biotechnology Reports 19: e00274.
Younes, I. \& Rinaudo, M. 2015. Chitin and chitosan preparation from marine sources. Structure, properties and applications. Marine Drugs 13(3): 1133-1174.

Aisyah Nabila Idris, Tang Swee Seong \& Ahmad Faris Mohd Adnan*

Institute of Biological Sciences

Faculty of Sciences

University of Malaya

50603 Kuala Lumpur, Federal Territory

Malaysia

Ahmad Faris Mohd Adnan*

Centre of Ionics

University of Malaya

50603 Kuala Lumpur, Federal Territory

Malaysia

*Corresponding author; email: ahmad_farisz@um.edu.my

Received: 16 June 2019

Accepted: 17 July 2020 